\title{
WORK INTEGRATED LEARNING IN INFORMATION TECHNOLOGY EDUCATION
}

\author{
Patrick Poppins and Mohini Singh \\ School of Business Information Technology, RMIT University, Australia \\ patrick.poppins@rmit.edu.au and Mohini.Singh@rmit.edu.au
}

\begin{abstract}
Work integrated learning, generally referred to internship programs in university undergraduate degrees provides graduates with real-life learning before they face the real world as an Information Technology graduate. This paper presents and discusses the process of managing work integrated learning in the IT undergraduate program at RMIT University. It also highlights the benefits and challenges to students, coordinators and the industry.
\end{abstract}

Key words: Work integrated learning, internship programs, cooperative education.

\section{INTRODUCTION}

This paper discusses real-life learning with WIL (work integrated learning) in the Information Technology undergraduate program at RMIT University in Melbourne. It discusses the role of WIL, the process of managing WIL, advantages, challenges and its future.

Incorporating mandatory Work Integrated Learning into an academic course is becoming popular with many tertiary institutions to provide IT students with real-life learning. RMIT University's Business Portfolio incorporates a year-long work integrated learning in the undergraduate program by placing students in industry, in the areas of Economics, Marketing, Accounting, Management and Information Technology. This unit of study is generally called co-operative employment. The university has employed this model of learning for the last 20 years, forming strong links with industry and with formal methods of assessment and monitoring student 
learning while they are with industry. This includes rigorous training in preparing students prior to placement using a process similar to a real, competitive job search process. The process of training students, monitoring their progress with industry, benefits of WIL and challenges is discussed.

\section{LITERATURE REVIEW}

Work Integrated Learning is the current term for what has been known in education for the last forty years as internship, sandwich year or cooperative education (Edmunds, 1999 and McLuskie and Zipf, 2003). It is a period (or periods) of time in a tertiary degree program curriculum where the student becomes immersed in the pursuit of professional work in industry. Providing students with real-world experiences is one of the best methods to prepare them to be successful in their careers (Fox, 2002). Carpenter (2003) refers to work integrated learning as 'internship', and describes it as on-the-job experience prior to graduation. He further explains that meaningful internships are based on formal learning objectives and these learning objectives should be part of a complete curriculum. Practical internship programs described by Carpenter entail formal partnerships between businesses and educational institutes where expectations and responsibilities of all parties are precisely defined. Fields (1996) emphasized that internships give students an employment edge, resulting in a job offer. It helps the students to 'test out' and gain experience in their chosen career field as well as networking and employment opportunities (Centre for Career Development, 2004) Fields (1996) further supports this by emphasising that with an internship a company has an opportunity to look at the student and vice versa. Fang, Lee and Huang (2004) also advocate that new employees with internship experience received greater entry-level compensation than non-interns and time to obtain their first positions was significantly shorter.

Edmunds (1999) suggests that by placing students in industry there is a presumption that employers, universities and students learn from the experience. Students especially are able to integrate theory with practice, mature, become more self confident and gain experience of the world of work. Smithers (1976), cited in Edmunds (1999) emphasised that the period of time spent in industry also increases student motivation and helps them acquire greater skills in human relations. Fang, Lee and Huang (2004) are of the opinion that in the current job market for IT graduates, which is not as favourable as it used to be five years ago, an internship program experience becomes more important than other factors in obtaining a position.

Although literature highlights several advantages of the internship program to the students and the employers, universities managing and 
monitoring student internships face several challenges. In the next section we will present the internship system for Business Information Technology students at RMIT University and discuss process, advantages and challenges.

\section{WORK INTEGRATED LEARNING (WIL) FOR BACHELOR OF BUSINESS IT}

The School of Business Information Technology at RMIT has used WIL for the last 20 years in a four year degree program with a one year industry placement in the third year. The WIL is placed in the later part of the degree program to ensure that students have sufficient professional skills to undertake work in industry. At the end of WIL students are able to complete the final part of their studies by undertaking some capstone subjects, as well as choosing electives. The industry experience has a marked influence on what students choose to study in their electives in final year. Figure 1 below presents the structure of the Bachelor of Business in Information Technology program that is discussed in this paper.

\begin{tabular}{|l|}
\hline $\begin{array}{l}\text { Final Year } \\
\text { (8 Courses) }\end{array}$ \\
\hline WIL Year \\
\hline Second Year \\
(8 Courses) \\
First Year \\
(8 Courses) \\
\hline
\end{tabular}

$$
\begin{aligned}
& \hookleftarrow 2 \text { IT Capstone, 1x Professional, 5x Electives (usually IT) } \\
& \hookleftarrow \text { Work in IT Industry, (with study deprecated or limited) } \\
& \hookleftarrow 4 x \text { IT core, 3x Business, 1x Elective, WIL Preparation } \\
& \hookleftarrow 4 x \text { IT core, 4x Business }
\end{aligned}
$$

Figure 1: Structure of the Undergraduate Course in Business IT at RMIT

In the first two years the courses provides knowledge of three IT streams: operating systems, hardware \& communications; applications development; and systems analysis and design. The core business subjects of accounting, economics, management, marketing and law also have to be successfully completed. Integral to the second year is a subject that prepares the students for WIL in their third year. The year students spend in industry is equivalent to one subject. In the final year, the focus is on capstone subjects addressing issues of systems implementation, professional practice \& IT specialisations.

\subsection{WIL Management Process}

The school has appointed a coordinator for WIL; an academic to manage the process of placing and assessing students in industry. At the beginning of the second year of their studies students are expected to register for WIL and 
are asked to indicate their IT preference. To assist students at the decision making stage the coordinator sends an email pointing them to www.gradlink. edu.au/content/view/full/238. Built by the Australian Computer Society, this site lists and describes careers in IT. The real preparation for WIL commences with a second year subject, delivered weekly with lectures on:

- The role of WIL in the course and how it works;

- Resume writing;

- Covering Letter writing;

- Interview techniques;

- Job search techniques - emphasis is on students tackling the real world in search of jobs via the visible and hidden job markets; and

- Ethics in the workplace.

Although most of the students have some previous work experience it is rarely in the area of IT. The WIL preparation classes are designed primarily to prepare students for job search within their profession, and implore them to be fastidious in their paper documents, honest in their claims, neither understating nor overstating their skills. Interview techniques sessions prepare students to respond to common questions from their own experiences and to a variety of interviewers. During the preparation lectures, students are taught how to apply for jobs. At the end of second year students apply for places in companies that offered jobs through RMIT. They are allowed to seek their own job placements. This process is described in detail in the next section. To manage student responses, the University has designed a number of forms to capture the necessary information. These are:

The Registration Form. This captures student data and is used in advising employers about a prospective applicant. A section of this form is devoted to initiate students thinking about fields of employment in their WIL year. It begins with subjects they have enjoyed or done well at, introduces professional titles, and gets them to select a ranking from a list. URLs with Graduate Career details of titles and occupations within ICT Industry are given to students to help them understand positions and job descriptions.

Employment Record. Once a student has found a position, this form is used to capture information on the student's employment details: name of company that they are working with, position they have been offered, their contact and salary level. They are also asked to provide details of their supervisors so that the School has an up to date record of where students are, what level positions they hold and who their supervisors are.

The Job Search Statistics. Because all jobs are won on a competitive, real world basis, this form collects data on the methods students used to find a job, number of applications made, and sources of job vacancies eg, newspapers, the Internet, other networks or the University. The analysis of 
this data enables the coordinator to target employers and to prepare students for industry placements in the following year.

Review of Job Search. This form gets students to review what was learnt in the process of seeking a job placement and what were the highlights. It reviews the effectiveness of preparatory classes. Most of the data captured are collated on a database and analysed for improvements in the process of placing students, following their assessments while they are on the job and to keep updated records in the School of as many as 150 students each year.

For the last 20 years RMIT University has employed this system of WIL in most Business undergraduate programs. In the process it has developed a very good rapport with a large number of employers who continue to support RMIT to fulfil the WIL requirement for their students and also depend on these students for positions in their organisations. The employers generally appreciate early graduate recruitment (try before you buy) or they have need for emerging IT skills. It is also cost effective for these organizations. These companies contact the School with their requests which are disseminated to students via email, asking them to respond within five days. Applications are briefly scanned for quality, and student activity noted. At this point control is handed over to the employer to follow through with their normal selection process. Students are also allowed to seek their own placement.

\subsection{Nature of Work in Industry}

The nature of work that graduates of program generally get involved in are that of business analysts, software support, network analysts and programmers. Therefore it is important that work integrated learning during their course of studies is geared to give them experience in these roles. To ensure this the WIL coordinator provides simple rules for industry placement based on the following criteria:

1. That approximately $90 \%$ of the student's time with the business in which they are placed will be spent with software and computer systems. It is most desirable that hardware management, computer operating, data entry or basic clerical duties are below $10 \%$ of a student's productive time. Working with software can include software development, maintenance, support, teaching, training, designing, documenting, configuring, testing, metrication, auditing and selling.

2. A student must have either an IT trained or qualified supervisor.

\subsection{How Students are Selected}

The School plays no part in the selection process beyond confirming the students' academic record to the employer if requested. Students are 
interviewed by the organisations based on employers selection criteria which can include the modes of telephone interviews, aptitude tests, comprehension tests, panel and interviews.

\subsubsection{Employer Description}

Employers tend to be from SMEs but there are a few of the large employers such as Ernst and Young, KPMG and Coles-Myer that assist the University with student work integrated learning. These employers are sought from various avenues both in the IT industry itself and from IT departments in other industries. A number of business organisations with which students are placed are shown on a web site www.rmitbit.net/co-op to show prospective employers and encourage students. A small but growing category of employers who have been sought out by students, are those that have an IT department. Additionally some employers have been found through student networks, family, friends, neighbours and acquaintances.

\subsubsection{Feedback}

The students complete four assignments during the year while they are in industry. These assessment requirements cover different aspects of business IT issues requiring them to be able to describe the organization they are working with, note taking and record keeping of events, problems, other technical and non-technical issues as well as equipment use. The final assignment is to author a professional business report -5000 words.

\subsubsection{Remuneration}

While the students are with industry they earn as much as $\$ A 22 \mathrm{~K}$ to $\$ A 28 K$. Some large organizations may pay up to $\$ A 30 \mathrm{~K}$ and sometimes more. Each year there a few students $(5 \%-10 \%)$ who are not able to find a job placement and for who the school has developed a course titled 'professional skills development'. This is done in-house with a simulated work environment. However, since this is without any payment most students make a great effort to be placed in industry.

\subsubsection{Benefits of WIL in IT Education}

Students attain job seeking techniques as they prepare for a job placement in their course of studies. The students learn to prepare good application documents, interview skills and job search techniques which make them aware and ready for a job later in life. 
Students graduate a year later with twelve months work experience in the area of IT. This enables them to find employment in a very short period of time after they graduate. Thirty percent of these students get a job with the employer they were placed with and ninety percent find a job within a month after graduation(graduates with IT work experience and Job search skills don't wait around for jobs). Organisations that employ the graduates who had done their WIL with them obviously had a chance to try these students before offering them ongoing positions. Students also get a chance to know the organization before they accept positions with them.

The impact of WIL on IT graduates also includes a high level of understanding of technology, it increases the standard of their work, provides experience that fosters maturity in approach to life, the disciplined environment of work focuses students to more diligently apply theory learnt. It also gives them a career direction. Graduates are able to combine theory with practice and gain a greater depth of knowledge and understanding.

Starting salaries for these graduates were usually higher than a graduate with no job experience giving them a competitive edge over other applicants for the same jobs. The employers get input from highly motivated preprofessionals who bring with them new perspectives to old problems. They also benefit from flexible cost-effective work force not requiring long term employment commitment. They get to evaluate potential employees before they recruit as they enhance their image in the community by developing strong links with the University. The WIL program in the undergraduate program is not a common practice at many other universities therefore this attracts many excellent students with high scores to choose the program for their tertiary education.

\section{PROBLEMS}

Although work integrated learning has many benefits in an undergraduate program and to students it is faced with some of the following problems. WIL management process entails extensive paperwork at the time of placing students, monitoring their progress and assessment. In one year as many 150 students undertake WIL, the management of which is a lot of work for the coordinator. At present an academic who has to spend a lot of time doing clerical work manages WIL in the school.

The students who are placed in industry sometimes take time adjusting to a full time job. Some find nine to five, five days a week on the job to be very demanding. At the same time they have four assessment requirements to complete and submit, therefore experience a heavy workload. Some students find it difficult to become a student again after being in the corporate 
environment for a year. The dress code, reduced income, relationship with peers and academics and the university system is a major change some of them have to cope with. At the end of WIL many students continue working with the organization and thus complete their degrees on a part time bases. This leads to low numbers in the final year of the degree.

\section{DISCUSSION AND CONCLUSION}

The perceived feedback from participants of the program has indicated what many authors have been saying for some time, and that is realizing, focusing and tackling the job market with WIL incorporated in the IT undergraduate program has many benefits. The work based reflective learning attained from WIL is valued by all IT graduates of the school. These graduates gain professional knowledge with academic and practical skills once they complete their qualifications. Therefore work integrated learning in IT education is a valuable and important part of the curriculum providing students with real-life learning before they enter the workforce.

WIL in the undergraduate program has also led to a close and strong relationship between the university and industry. Although this scheme is not available in many other universities and future government funding for WIL is in question, RMIT University will continue incorporating WIL in the IT curriculum due to its enormous advantages.

\section{REFERENCES}

Carpenter, D. A., 2003, 'Meaningful Information Systems Internships', Journal of Information Systems Education, Vol 14, Iss 2, pp 201- 210.

Centre for Career Development, 2004. http://www.city.ac.uk/careers/

Edmunds, M., 1999, 'Quality in sandwich year', Quality Assurance in Education, Volume 7 Number 2, pp 101-112.

Fang, X., Lee, S., Lee, T. and Huang, W., 2004, 'Critical Factors Affecting Job Offers for New MIS Graduates', Journal of Information Systems Education, West Lafayette, Summer, Vol 15, Iss 2, page 189- 204.

Fields, C. D., 1996, 'Business Schools and Employment', Black Issues in Higher Education', Reston, Volume 13, Iss 21, pp $16-17$.

Fox, Michael, 'E-Learning', Duluth: Mar 2002.Volume 3, Iss 3; pg. 26, 4 pgs

Gerrand, J. Saunderson, H. 'Compulsory Versus Optional Co-operative Programs, The Journal of Cooperative Education, 1, pp 46-56.

McLuskie, L. and Zipf, R.,2003, 'Collegiality: the foundation of a successful internship program', Working Paper, Central Queensland University, Australia. 